\title{
Basal Cell Nevus with Comedones
}

National Cancer Institute

\section{Source}

National Cancer Institute. Basal Cell Nevus with Comedones. NCI Thesaurus. Code C4749.

A type of pilosebaceous hamartoma characterized by basal cell epitheliomata, epidermoid cysts and comedones, and epidermal atrophy. 